\section{Effect of Flaxseed Supplementation of Feed on Growth, Carcass Yield, Meat and Fatty Acids Profile of Rabbit Carcass}

\author{
Kamran Khan', Sarzamin Khan ${ }^{2}$, Nazir Ahmad Khan ${ }^{2, *}$ and Naseer Ahmad ${ }^{2}$ \\ ${ }^{1}$ Department of Animal Sciences, Shaheed Benazir Bhutto University, Sheringal, \\ Khyber Pakhtunkhwa \\ ${ }^{2}$ Faculty of Animal Husbandry and Veterinary Sciences, The University of Agriculture, \\ Peshawar 25130, Khyber Pakhtunkhwa
}

\begin{abstract}
A B S T R A C T
The aim of this study was to quantify the effect of two concentrations and technological forms of flaxseed supplementation on growth performance, carcass yield and meat quality of rabbits. Sixty indigenous rabbits were divided randomly into five treatment groups. The control group was fed on standard concentrate basal diet, whereas in the treated groups, the basal diet was supplemented with low (3.5\%; LCF) or high (7\%; HCF) level of crushed flaxseed and low (1.5\%; LFO) or high ( $3 \%$; HFO) level of flaxseed oil until slaughtering (day 90). Carcass fat deposition was greater $(\mathrm{P}<0.05)$ in the supplemented groups as compared to the control group. The contents of myristic acid and palmitic acid reduced $(\mathrm{P}<0.05)$, while those of linoleic acid and linolenic acid increased $(\mathrm{P}<0.05)$ in the carcass of all supplemented groups. Moreover, the supplemented groups had lower $(\mathrm{P}<0.05) n-6: n-3$ ratio than the control group. Among the supplemented groups, HFO supplemented group had higher $(\mathrm{P}<0.05)$ contents of total polyunsaturated FA and lower $(\mathrm{P}<0.05) n-6: n-3$ ratio. This study provides the first dataset on carcass yield and quality, physicochemical characteristics, and FA profile of indigenous rabbits and shows that supplementation of flaxseed favorably modulates the FAs composition of rabbit meat, with no negative effect on their growth performance and meat physicochemical quality.
\end{abstract}

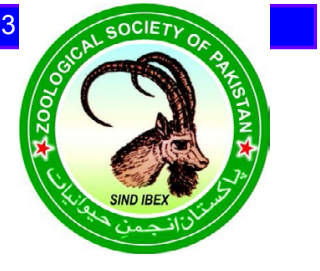

CrossMark

\section{INTRODUCTION}

$\mathrm{O}$ verall, Asia accounts for $48.8 \%$ of global rabbit meat production, and most of the rabbit meat is produced under small scale production systems, such is in Pakistan (FAOSTAT, 2012). The Northern areas of Pakistan hosts the largest rabbit population of the country, and these rabbits are reared under small-holder subsistence production system for meat, livelihood and as pet animals (Khan et al., 2014). Rabbit production is still a new farming enterprise, and over the past decade, it has rapidly grown from family consumption to medium and large scale commercial production. Recent studies show that indigenous rabbits can produce meat more efficiently in the intensive farming system with improved feeding and management (Khan et al., 2017a, b). With proper feeding rabbit meat can present excellent dietetic and nutritional properties (Hernandez et al., 2008), such as lower cholesterol contents and a higher linolenic acid (C18:3n-3) contents (Arino et al., 2007), which can benefit long term human health by reducing the risks of obesity,

\footnotetext{
Corresponding author: nazir.khan@aup.edu.pk 0030-9923/2018/0006-2037 \$ 9.00/0 Copyright 2018 Zoological Society of Pakistan
}

cardiovascular diseases and type-2 diabetes ( $\mathrm{Hu}$ and Willett, 2002). This background provides an impetus to fully exploit the potential of rabbit for quality meat production.

Research in the past two decades has shown that next to fat content, the nutritional quality and healthiness of meat is mainly influenced by its fatty acids (FA) profile (Kanatt et al., 2006). There is a growing consumer preference for animal products that are enriched with beneficial unsaturated FAs. Next to water and protein, fats are the major component of meat. The fat content of meat is highly variable in terms of quantity and quality. The fat content is mostly influenced by the genetics, age and nutrition of the animal, whereas the FA profile is mainly influenced by the diet of the animal (Hernandez et al., 2008). The meat researchers aimed to produce meat with lower fat content having lower content of saturated FA (SFA) and higher content of unsaturated FA (UFA) to benefit long term human health. Like other monogastric animals, rabbits are able to incorporate dietary FAs into adipose tissue and intramuscular fats, thus making it possible to modulate the FAs profile of rabbits through the strategic use of unsaturated dietary fat sources such as flaxseed.

Flaxseed (Linum usitatissimum L.), also known as 
linseed, is receiving growing attention from the feed industry due to its oil content, which is about $40 \%$ on a dry matter (DM) basis (Peiretti et al., 2007; Khan et al., 2015a). Moreover, the oil contains a high proportion of linolenic acid (C18:3n-3; Khan et al., 2014), and recent research indicates that rabbits receiving flaxseed enriched diets produces meat with a high proportion of mega-3 FAs (Kouba et al., 2008). This has led to a renewed interest in feeding of flaxseed to livestock to favorably modulate the FAs composition of milk and meat. However, to the author's knowledge, no systematic research has been conducted to determine the effect of flaxseed supplementation on the FA profile of rabbit meat. Therefore, the present study was designed to quantify the growth performance, carcass yield, physicochemical quality and FA profile of rabbit meat in Northern Pakistan, and further evaluated the effect of supplementing low $(3.5 \%$; LCF) or high $(7 \%$; HCF $)$ concentrations of crushed flaxseed, and low (1.5\%; LFO) or high $(7 \%$; HFO) concentrations of flaxseed oil on the FA profile of rabbit meat.

\section{MATERIALS AND METHODS}

\section{Rabbit selection and experimental design}

In the present research study, a total of sixty local rabbits ( $58 \pm 3$ days old; weight, $565 \pm 5.1 \mathrm{~g}$ ) were selected from the rabbit herd at the Rabbit Research Center of the University of Agriculture Peshawar. The experimental rabbits were divided into five dietary groups according to randomized complete block design. The blocks were balanced for age and body weight. Each dietary group consisted of 12 rabbits. Five iso-nitrogenous and iso-caloric concentrates were formulated (Table I). The control diet contain commercial concentrate as a basal diet, whereas in the treated groups low $(3.5 \%$; LCF) or higher $(7 \%$; HCF) levels of crushed flaxseed, and low (1.5\%; LFO) or high $(3 \%$; HFO) levels of flaxseed oil were included in the control diet, as a replacement of yellow corn and soybean meal. The basal diet was formulated according to NRC (1977) and was converted into a pellet form at the feed processing unit of Agriculture University Peshawar. The ingredient composition of the basal diet is given in Table I. The experimental trial continued for 5 weeks including a week of the adaptation period at the Rabbit Research Center of the University of Agriculture Peshawar, and the experimental procedure was approved by the ethical committee of the University for Procedures involving the care, live rabbit handling, welfare, and standard laboratory protocols.

\section{Data collection}

Body weight was recorded weekly and the average daily gain was calculated. Daily feed intake and feed conversion ratio were computed by measuring individual feed intake and weight. At 90 days of age, all the rabbits were slaughtered by cutting the carotid arteries and jugular veins. The carcass procedure was carried out with the standard procedure of the World Rabbit Science Association as reported by Khan et al. (2016). The $\mathrm{pH}$ was measured $24 \mathrm{~h}$ postmortem in triplicate on samples taken from right hind legs with a digital $\mathrm{pH}$ meter (JENWAY 3505 , UK). Meat physical quality was determined on meat samples from left hind legs according to standard procedure for percentage of released water (Grau and Fleischmann, 1957), and cooking loss (Boccard et al., 1981). Chemical composition was measured on a meat sample from forelegs according to the standard method of the Association of Official and Analytical Chemist (1990).

Table I.- Ingredients (\%) composition of the experimental diets.

\begin{tabular}{|c|c|c|c|c|c|}
\hline \multirow[t]{2}{*}{ Ingredients } & \multirow[t]{2}{*}{ Control } & \multicolumn{4}{|c|}{ Treated groups $^{1}$} \\
\hline & & LCF & HCF & LFO & HFO \\
\hline Alfalfa hay & 27 & 28 & 30 & 30 & 34 \\
\hline Yellow corn & 23.5 & 20 & 9.4 & 20 & 10 \\
\hline Barley grain & 5.4 & 5.4 & 7.5 & 5.4 & 8.5 \\
\hline Wheat bran & 27 & 27 & 33 & 27 & 31.4 \\
\hline Soybean meal & 15 & 14 & 11 & 14 & 11 \\
\hline Crushed Flaxseed & 0 & 3.5 & 7 & 0 & 0 \\
\hline Flaxseed oil & 0 & 0 & 0 & 1.5 & 3 \\
\hline Di-Ca-Phosphate & 1 & 1 & 1 & 1 & 1 \\
\hline DL-Methionine & 0.1 & 0.1 & 0.1 & 0.1 & 0.1 \\
\hline Sodium chloride & 0.5 & 0.5 & 0.5 & 0.5 & 0.5 \\
\hline Vit and Min. Premix ${ }^{2}$ & 0.5 & 0.5 & 0.5 & 0.5 & 0.5 \\
\hline
\end{tabular}

${ }^{1} \mathrm{LCF}$, low $(3.5 \%)$ or HCF, high (7\%) concentration of crushed flaxseed. LFO, low (1.5\%) or HFO, high $(3 \%)$ concentration of flaxseed oil. ${ }^{2}$ Premix provided per $\mathrm{kg}$ of diet: Biotin, $33 \mathrm{mg}$; Choline chloride, 200 g; Co, $16.6 \mathrm{mg}$; Fe, $12.5 \mathrm{~g}$; Folic acid, $0.83 \mathrm{~g}$; Mg, $66.7 \mathrm{~g}$; Mn, $5 \mathrm{~g}$; Pantothenic acid, 3.33 g; Se, $16.6 \mathrm{mg}$; Vit. A, 2000 IU; Vit. D, 150 IU; Vit. E, 8.33 g; Vit. K, 0.33 g; Vit. B1, 0.33 g; Vit. B2, 1.0 g; Vit. B6, $0.33 \mathrm{~g}$; Vit. B5, $8.33 \mathrm{~g}$; Vit. B12, $1.7 \mathrm{mg}$; Zn, $11.7 \mathrm{~g}$.

\section{Chemical analysis}

The sample of each diet was ground at 1-mm particle size and analyzed for the contents of DM (method 930.15), ether extract (EE, method 920.39), crude protein (CP; method 984.13; using a Kjeltec ${ }^{\mathrm{TM}} 2400$ auto analyzer; Foss Analytical A/S, Hillerød, Denmark) and acid detergent fiber (ADF; method 973.18) according to the standard procedures of AOAC (1990). The NDF content was determined according to the procedure of Van Soest et al. (1991), with some modification in the use sodium sulphite and heat-stable $\alpha$-amylase for the correction of residual starch and protein as described by Habib et al. (2016). 
Table II.- Chemical and fatty acid (g per $100 \mathrm{~g}$ of all acids determined) composition of experimental diets.

\begin{tabular}{|c|c|c|c|c|c|}
\hline \multirow[t]{2}{*}{ Chemical Analysis $^{2}$} & \multirow[t]{2}{*}{ Control } & \multicolumn{4}{|c|}{ Treated groups $^{1}(\%)$} \\
\hline & & LCF & HCF & LFO & HFO \\
\hline Dry matter & 89.3 & 90.1 & 90.2 & 90.3 & 90.5 \\
\hline Crude protein & 15.3 & 15.5 & 15.6 & 15.7 & 15.8 \\
\hline Ether extract & 3.34 & 4.32 & 5.34 & 5.40 & 5.51 \\
\hline Neutral detergent fiber & 34.2 & 35.6 & 36.7 & 36.5 & 36.6 \\
\hline Acid detergent fiber & 16.8 & 17.6 & 17.9 & 18.6 & 18.9 \\
\hline \multicolumn{6}{|l|}{ Fatty acid, (g/100 g) } \\
\hline $\mathrm{C} 14: 0$ & 0.53 & 0.37 & 0.35 & 0.25 & 0.18 \\
\hline C16:1 & 0.22 & 0.56 & 0.63 & 0.63 & 0.76 \\
\hline C16:0 & 16.3 & 12.5 & 12.3 & 12.5 & 11.6 \\
\hline C18:0 & 2.43 & 2.30 & 2.23 & 2.14 & 2.00 \\
\hline $\mathrm{C} 18: 1 \mathrm{c}$ & 20.4 & 27.5 & 28.5 & 30.0 & 30.5 \\
\hline C18:1n9T & 0.32 & 0.54 & 0.61 & 0.62 & 0.67 \\
\hline C20:0 & 0.57 & 0.46 & 0.47 & 0.47 & 0.44 \\
\hline $\mathrm{C} 22: 0$ & 0.49 & 0.41 & 0.41 & 0.41 & 0.32 \\
\hline $\mathrm{C} 22: 1$ & 0.12 & 0.31 & 0.32 & 0.31 & 0.32 \\
\hline C18:2n6 & 32.6 & 34.2 & 34.8 & 35.6 & 36.5 \\
\hline C20:5n 3 & 0.00 & 0.57 & 0.62 & 0.54 & 0.67 \\
\hline $\mathrm{C} 18: 3 \mathrm{n} 3$ & 6.75 & 15.0 & 15.3 & 15.2 & 15.6 \\
\hline $\mathrm{C} 22: 6 \mathrm{n} 3$ & 0.00 & 1.04 & 1.05 & 1.03 & 1.06 \\
\hline$\sum \mathrm{SFA}^{3}$ & 20.3 & 16.0 & 15.8 & 15.8 & 14.5 \\
\hline$\sum$ MUFA $^{4}$ & 21.1 & 28.9 & 30.1 & 31.6 & 32.2 \\
\hline$\sum$ PUFA $^{5}$ & 39.4 & 50.8 & 51.8 & 52.4 & 53.8 \\
\hline
\end{tabular}

See Table I. ${ }^{2}$ Calculated according to NRC (1977). C14:0, myristic acid; C16:0, palmitic acid; C16:1, palmitoleic acid; C18:0, steraic acid; C18:1c, vaccenic acid; C18:1n-9, oleic acid; C18:2n6, linoleic acid; C18:3n-3, linolenic acid; C20:0, arachidic acid; C22:0, behenic acid; C22:1, Erucic acid; C20:5n3, eicosapentaenoic acid; $\mathrm{C} 22: 6 \mathrm{n} 3$, docosahexaenoic acid. ${ }^{3}$ Saturated fatty acid. ${ }^{4}$ Mono unsaturated fatty acid. ${ }^{5}$ Polyunsaturated fatty acid.

\section{Fatty acids analysis}

For FA analysis of diets and meat (longissimus dorsi muscles), lipids from freeze dried, grounded samples were extracted with chloroform-methanol (2:1 v/v; Folch et al. (1957) with slight modification as described by Khan et al. (2011). After extraction, FAs in the residual fat were esterified, using acid and base catalyzed methods as described by Khan et al. (2015b). Fatty acid methyl esters (FAMEs) analysis was performed by gas chromatographymass spectrometry (GC-MS; Shimadzu-QP 2010 plus, Japan) equipped with electron impact (EI) detector. Separations of FAs were carried out on capillary column TRB-FFAP $(30 \mathrm{~m} \times 0.32 \mathrm{~mm} \times 0.25 \mu \mathrm{m})$ using Helium as carrier gas. Column temperature was held at $50^{\circ} \mathrm{C}$ for $1 \mathrm{~min}$, and then the temperature was raised up to $150^{\circ} \mathrm{C}$ at the rate of $15^{\circ} \mathrm{C}$ per min. Then the temperature was increased to $175^{\circ} \mathrm{C}$ at the rate of $2.50^{\circ} \mathrm{C}$ and hold for 5 min and finally increased to $220^{\circ} \mathrm{C}$ at the rate of $2.50^{\circ} \mathrm{C}$ per min and kept for $5 \mathrm{~min}$. The peaks were identified by 37 components of the FAME standard mix (S37, Supelco, Bellefonte, PA, USA) accompanied by MS library.

\section{Statistical analysis}

The effect of diets on the performance, carcass yield, dressing percentage, meat physicochemical quality and FA profile of rabbit meat was determined using PROC MIXED Procedure of the Statistical Analysis System (SAS, SAS Institute Inc., Cary, NC)

$$
Y_{i j=} \mu+D_{i}+C_{i j}
$$

Where, $Y_{i j}$ is the response of the dietary treatments, $\mu$ is the population mean, $\mathrm{F}_{\mathrm{i}}$ is the fixed effect of diets $(\mathrm{i}=$ control, LCF, HCF, LFO and HFO diets) and $\epsilon_{\mathrm{ij}}$ is the random error.

When significant effects were observed post-hoc analysis were carried out using Tukey-Kramer test to computed pair-wise differences in the treatment means.

\section{RESULTS}

Data on the chemical composition and FA contents of experimental diets are summarized in Table II. The ether extract content was higher in diets supplemented with flaxseed as compared to the control group. The flaxseed supplementation to the basal diet reduced the contents of myristic acid (C14:0), palmitic (C16:0) and total SFA, and increased the contents of total UFA, C18:3n-3 and total polyunsaturated FA (PUFA).

Table III.- Effect of concentration and technological form of flaxseed supplementation on the growth performance and carcass yield of indigenous rabbits.

\begin{tabular}{lcccccccc}
\hline & Control & \multicolumn{4}{c}{ Diets $^{1}$} & \multicolumn{3}{c}{ SEM $^{\mathbf{2}}$ Sig $^{*}$} \\
\cline { 3 - 8 } & & LCF & HCF & LFO & HFO & & \\
\hline Final weight(g) & 1205 & 1207 & 1214 & 1205 & 1210 & 1.57 & $\mathrm{~ns}$ \\
AWG (g/d) & 18.2 & 18.4 & 18.6 & 18.3 & 18.5 & 0.08 & $\mathrm{~ns}$ \\
Feed intake & 99.9 & 100.2 & 101.3 & 99.2 & 100.9 & 0.964 & $\mathrm{~ns}$ \\
(g/d) & & & & & & & \\
FCR & 5.47 & 5.45 & 5.43 & 5.42 & 5.44 & 0.057 & $\mathrm{~ns}$ \\
C. wt (g) & 659 & 663 & 669 & 661 & 666 & 3.57 & $\mathrm{~ns}$ \\
Dressing (\%) & 54.5 & 54.6 & 54.9 & 54.5 & 54.7 & 0.34 & $\mathrm{~ns}$ \\
Liver (g) & 55.2 & 54.5 & 56.3 & 57.1 & 56.4 & 2.37 & $\mathrm{~ns}$ \\
Kidney (g) & 8.98 & 9.23 & 9.28 & 9.49 & 9.20 & 0.31 & $\mathrm{~ns}$ \\
Heart (g) & 4.20 & 4.34 & 4.21 & 4.30 & 4.24 & 0.06 & $\mathrm{~ns}$ \\
Lungs (g) & 9.12 & 9.20 & 8.99 & 9.10 & 9.34 & 0.04 & $\mathrm{~ns}$ \\
\hline
\end{tabular}

See Table I. ${ }^{2}$ Standard error of the mean. ${ }^{*} \mathrm{P}>0.05$. FCR, feed conversion ratio; AWG, average weight gain; C. wt, carcass weight; Sig, significance.

Data on the effect of type and concentration of flaxseed 
supplementation on the growth performance, carcass yield and organ weight are summarized in Table III. Live body weight, feed consumption and feed conversion efficiency did not differ $(\mathrm{P}>0.05)$ due to different concentrations of flaxseed supplementation. Similarly, carcass weight, dressing percentage and organ weight did not differ due to dietary treatments. Table IV summarizes data on physicochemical characteristics of rabbits as affected by the type and concentration of flaxseed supplementation. The meat physical quality such as $\mathrm{pH}$, percentage of water release and cooking losses did not differ $(\mathrm{P}>0.05)$ due to flaxseed supplementation. The contents of moisture, crude protein and ash also did not differ; however, the contents of fat were higher $(\mathrm{P}<0.05)$ in the supplemented groups.

Table IV.- Effect of concentrations and technological form of flaxseed supplementation on the physicochemical quality of indigenous rabbits.

\begin{tabular}{lcccccccc}
\hline & Control & \multicolumn{3}{c}{ Diets $^{1}$} & SEM $^{2}$ & Sig $^{*}$ \\
\cline { 3 - 7 } & \multicolumn{9}{c}{ LCF } & HCF & LFO & HFO & & \\
\cline { 1 - 6 } Chemical quality (Fore legs, \%) \\
Moisture & 70.6 & 71.5 & 71.7 & 70.9 & 71.6 & 0.747 & ns \\
Protein & 21.4 & 21.7 & 20.9 & 21.1 & 20.7 & 0.366 & ns \\
Fat & $7.32^{\mathrm{b}}$ & $8.32^{\mathrm{a}}$ & $8.26^{\mathrm{a}}$ & $8.25^{\mathrm{a}}$ & $8.25^{\mathrm{a}}$ & 0.184 & $* *$ \\
Ash & 1.33 & 1.32 & 1.31 & 1.30 & 1.29 & 0.018 & $\mathrm{~ns}$ \\
Physical quality (hind legs) & & & & & \\
pH & 5.65 & 5.68 & 5.67 & 5.63 & 5.61 & 0.213 & $\mathrm{~ns}$ \\
Release & 15.9 & 16.1 & 15.6 & 15.4 & 15.8 & 0.457 & $\mathrm{~ns}$ \\
water (\%) & & & & & & & \\
Cooking & 34.8 & 35.6 & 36.1 & 35.4 & 35.1 & 0.923 & $\mathrm{~ns}$ \\
loss (\%) & & & & & & & \\
\hline 1,2 see Table III. & & & & & & &
\end{tabular}

Data on the effect of the concentration and type of flaxseed supplementation on meat FA profiles of indigenous rabbits, as affected by the technological form and concentration of supplementation, are presented in Table V. Inclusion of flaxseed in the diet reduced $(\mathrm{P}<0.05)$ the contents of $\mathrm{C} 14: 0, \mathrm{C} 16: 0$, stearic acid (C18:0) and total SFA as compared to the control group. The contents of monounsaturated FAs such as myristoleic acid (C14:1c), palmitoleic acid $\mathrm{C} 16: 1 \mathrm{c}$ and oleic acid (C18:1c) were higher $(\mathrm{P}<0.05)$ in the supplemented groups. Moreover, the contents of $\mathrm{C} 18: 2 \mathrm{n}-6, \mathrm{C} 18: 3 \mathrm{n}-3$ and total PUFA increased $(\mathrm{P}<0.05)$ with the supplementation of flaxseed in the diet. The ratio of $n-6: n-3$ FAs decreased in the supplemented groups as compared to control. Among the supplemented group the lowest $(\mathrm{P}<0.05)$ concentration of C14:0, C16:0, C18:0 and total SFA was recorded with the diets containing higher levels of flaxseed or flaxseed oil. Notably, rabbits supplemented with higher levels of flaxseed oil had higher $(\mathrm{P}<0.05)$ contents of $\mathrm{C} 18: 2 \mathrm{n}-6$, C18:3n-3 and total PUFA and lower $(\mathrm{P}<0.05) n-6: n-3$ ratio as compared to other supplemented groups.

Table V.- Effect of concentrations and forms of flaxseed supplementation on the meat fatty acid profile (\% of total methyl esters) of rabbit meat.

\begin{tabular}{|c|c|c|c|c|c|c|c|}
\hline \multirow{2}{*}{$\begin{array}{l}\text { Fatty } \\
\text { acids }\end{array}$} & \multirow[t]{2}{*}{ Control } & \multicolumn{4}{|c|}{ Diets $^{1}$} & \multirow[t]{2}{*}{ SEM $^{2}$} & \multirow[t]{2}{*}{$\mathrm{Sig}^{3}$} \\
\hline & & LCF & HCF & LFO & $\overline{\text { HFO }}$ & & \\
\hline C14:0 & $3.42^{\mathrm{a}}$ & $2.99^{b}$ & $2.62^{\mathrm{c}}$ & $2.79^{\mathrm{b}}$ & $2.60^{\mathrm{c}}$ & 0.081 & $* *$ \\
\hline C16:0 & $22.0^{\mathrm{a}}$ & $17.7^{b}$ & $14.9^{\mathrm{c}}$ & $14.7^{\mathrm{c}}$ & $13.8^{\mathrm{c}}$ & 0.464 & $* *$ \\
\hline C18:0 & $12.2^{\mathrm{a}}$ & $7.36^{b}$ & $5.29^{c}$ & $6.00^{\mathrm{b}}$ & $5.93^{\mathrm{c}}$ & 0.297 & $* *$ \\
\hline $\mathrm{C} 20: 0$ & $1.52^{\mathrm{a}}$ & $2.44^{\mathrm{a}}$ & $5.36^{\mathrm{b}}$ & $7.05^{\mathrm{b}}$ & $2.10^{\mathrm{a}}$ & 0.881 & $*$ \\
\hline $\mathrm{C} 22: 0$ & $0.24^{\mathrm{a}}$ & $0.15^{b}$ & $0.15^{\mathrm{b}}$ & $0.14^{\mathrm{b}}$ & $0.16^{\mathrm{b}}$ & 0.008 & $*$ \\
\hline C14:1c & $1.38^{\mathrm{c}}$ & $2.34^{\mathrm{b}}$ & $2.46^{\mathrm{ab}}$ & $2.90^{\mathrm{a}}$ & $2.95^{\mathrm{a}}$ & 0.087 & $* *$ \\
\hline $\mathrm{C} 16: 1 \mathrm{c}$ & $2.66^{\mathrm{b}}$ & $2.38^{c}$ & $2.90^{\mathrm{ab}}$ & $2.35^{\mathrm{c}}$ & $3.36^{\mathrm{a}}$ & 0.038 & $*$ \\
\hline $\mathrm{C} 18 \mathrm{:} 1 \mathrm{c}$ & $15.2^{\mathrm{c}}$ & $19.5^{b}$ & $21.9^{\mathrm{a}}$ & $19.9^{\mathrm{b}}$ & $21.0^{\mathrm{ab}}$ & 0.329 & $* * *$ \\
\hline C18:1n9T & & $1.75^{\mathrm{a}}$ & $1.56^{\mathrm{ab}}$ & $1.44^{\mathrm{ab}}$ & $1.41^{\mathrm{ab}}$ & 0. & $\neq$ \\
\hline $\mathrm{C} 22: 1$ & $0.10^{\mathrm{b}}$ & $0.52^{\mathrm{a}}$ & $0.58^{\mathrm{a}}$ & $0.45^{\mathrm{ab}}$ & $0.32^{\mathrm{ab}}$ & 0.058 & $*$ \\
\hline C18:2 n6 & $22.5^{\mathrm{a}}$ & $19.2^{\mathrm{b}}$ & $21.4^{\mathrm{b}}$ & $20.9^{\mathrm{b}}$ & $21.8^{\mathrm{a}}$ & 0.276 & $* *$ \\
\hline C20:5n 3 & $0.94^{\mathrm{c}}$ & $1.09^{\mathrm{b}}$ & $1.13^{\mathrm{b}}$ & $1.11^{\mathrm{b}}$ & $1.33^{\mathrm{a}}$ & 0.020 & $* * *$ \\
\hline $\mathrm{C} 18: 3 \mathrm{n} 3$ & $2.95^{\mathrm{d}}$ & $7.91^{\mathrm{c}}$ & $13.5^{\mathrm{b}}$ & $9.45^{\mathrm{c}}$ & $15.4^{\mathrm{a}}$ & 0.296 & $* * *$ \\
\hline $\mathrm{C} 20: 4 \mathrm{n} 6$ & $3.05^{\mathrm{a}}$ & $2.91^{\mathrm{ab}}$ & $2.99^{\mathrm{a}}$ & $2.61^{\mathrm{b}}$ & $2.99^{\mathrm{a}}$ & 0.089 & $*$ \\
\hline C20:3n6 & $0.23^{\mathrm{c}}$ & $0.26^{\mathrm{b}}$ & $0.34^{\mathrm{a}}$ & $0.21^{\mathrm{c}}$ & $0.33^{\mathrm{a}}$ & 0.005 & $* * *$ \\
\hline $\mathrm{C} 22: 6 \mathrm{n} 3$ & $0.07^{\mathrm{c}}$ & $1.15^{\mathrm{b}}$ & $1.40^{\mathrm{a}}$ & $1.23^{\mathrm{b}}$ & $1.58^{\mathrm{a}}$ & 0.095 & $*$ \\
\hline $\mathrm{SFA}^{4}$ & $39.4^{\mathrm{a}}$ & $30.6^{b}$ & $28.3^{\mathrm{c}}$ & $30.7^{b}$ & $24.6^{\mathrm{c}}$ & 0.499 & $* *$ \\
\hline MUFA $^{5}$ & $20.6^{\mathrm{b}}$ & $26.5^{\mathrm{a}}$ & $29.4^{\mathrm{a}}$ & $27.0^{\mathrm{a}}$ & $29.1^{\mathrm{a}}$ & 1.044 & $*$ \\
\hline PUFA $^{6}$ & $29.7^{\mathrm{e}}$ & $32.5^{\mathrm{d}}$ & $40.8^{b}$ & $35.5^{\mathrm{c}}$ & $43.4^{\mathrm{a}}$ & 0.126 & *** \\
\hline$n-6: n-3$ & $6.51^{\mathrm{a}}$ & $2.20^{\mathrm{b}}$ & $1.54^{\mathrm{c}}$ & $2.01^{\mathrm{b}}$ & $1.37^{\mathrm{c}}$ & 0.056 & $* *$ \\
\hline
\end{tabular}

See Table II, $\mathrm{P}<0.1 ;{ }^{*}, \mathrm{P}<0.05,{ }^{* *} \mathrm{P}<0.001 ;{ }^{* * *} \mathrm{P}<0.0001 .{ }^{4}$ Saturated fatty acid $=\mathrm{C} 14: 0+\mathrm{C} 16: 0+\mathrm{C} 18: 0+\mathrm{C} 20: 0+\mathrm{C} 22: 0 .{ }^{5}$ Mono unsaturated fatty acid $=\mathrm{C} 14: 1 \mathrm{c}+\mathrm{C} 16: 1 \mathrm{c}+\mathrm{C} 18: 1 \mathrm{c}+\mathrm{C} 18: 1 \mathrm{n} 9 \mathrm{~T}+\mathrm{C} 22: 1 .{ }^{6}$ Polyunsaturated fatty acid $=\mathrm{C} 18: 2 \mathrm{n} 6+\mathrm{C} 20: 5 \mathrm{n} 3+\mathrm{C} 18: 3 \mathrm{n} 3+\mathrm{C} 20: 4 \mathrm{n} 6+\mathrm{C} 20: 3 \mathrm{n} 6+$ $\mathrm{C} 22: 6 \mathrm{n} 3 . n-6: n-3=(\mathrm{C} 18: 2 \mathrm{n} 6+\mathrm{C} 20: 4 \mathrm{n} 6+\mathrm{C} 20: 3 \mathrm{n} 6) /(\mathrm{C} 20: 5 \mathrm{n} 3+$ $\mathrm{C} 18: 3 \mathrm{n} 3+\mathrm{C} 22: 6 \mathrm{n} 3)$.

\section{DISCUSSION}

Dietary supplementation of unsaturated fat can increase the content of UFAs with a concomitant decrease in SFA in animal products, and render it more beneficial to human health. More interest has been given by meat researchers to enhance the contents of PUFA, particularly the $n-3$ FAs in meat. The present study reports the first comprehensive data set on the FAs profile of indigenous rabbits in Northern Pakistan, and the transfer efficiency of dietary PUFA into rabbit meat. The database can be used to devise management and feeding strategies for the rabbits. 
The results showed that there was an excellent relationship between the content and composition of dietary PUFA with that of the longissimus dorsi muscle in rabbits.

In agreement with earlier findings (Trebusak et al., 2014), dietary supplementation of flaxseed did not significantly alter the diet intake, growth, carcass weight and composition of rabbits. Except fat, the contents of all other nutrients in the carcass were not altered by the supplementation of flaxseed. In agreement with our findings. Bianchi et al. (2006) found higher total fat deposition in the muscles with flaxseed supplementation. The cost incurred per kg of diet in PKR was highest (36.2) for HCF, followed by HFO (34.5), LCF (32.0), LFO (31.2), and control group (26.6), respectively. However, consumers pay premium prices for omeg-3 enriched eggs, and it is expected that high consumer prices may be possible for omeg-3 enriched meat and milk in the future.

Research has established that changes in the lipid composition of animal diet can alter the content and composition of meat fat (Bourre, 2004). In the present study, the PUFA concentrations in the longissimus dorsi muscles were increased by dietary inclusion of crushed flaxseed or flaxseed oil. On the other hand, the content of SFA decreased by feeding diets enriched with crushed flaxseed or flaxseed oil. Our results are consistent with earlier findings of Trebusak et al. (2011), who observed a higher PUFA and lower SFA contents with a more favorable $n-6: n$-3 FAs ratio in rabbit meat, with supplementation of flaxseed or sunflower in the basal diet. These findings highlight that inclusion of flaxseed in rabbit diets can improve the nutrition value of rabbit meat. Similarly, Gelibolu et al. (2018) reported positive effects of mannanoligosaccharide fed fish on the meat fatty acid profile. Research has shown that the concentration of C14:0 and C16:0 in human diet affects the level of lowdensity lipoprotein concentration in the plasma (Wood et al., 2004). On the other hand, C18:1cis-9 is desired for hypocholesterolemic action (Molkentin, 2000). Our results indicate that supplementation of flaxseed in rabbit diets can favorably modulate the FA profile of rabbit meat by lowering the concentration of $\mathrm{C} 14: 0$ and $\mathrm{C} 16: 0$, and by increasing the concentration of $\mathrm{C} 18$ : 1 cis- 9 as compared to control group. Linoleic and C18:3n-3 are the essential FAs due to their important functions in the structure of cellular membranes and metabolic processes. Their consumption is therefore desirable (Martin et al., 2006). Flaxseed is a rich source of the aforementioned essential FAs, which was reflected in the composition of the muscle in the rabbits. The $n-6: n-3$ FAs ratio is highly influenced by the FA composition of the diet fed to the animals (Raes et al., 2004). Lowering the ratio of $n-6$ to $n-3$ FA in food products have been recommended to prevent or modulate lifestyle diseases in humans (Russo, 2009). The ratio of $n-6$ to $n-3$ FA in food should range between 1 and 4 (Simopoulos, 2001). In accordance with various studies, degenerative diseases, such as diabetes, arthritis and cancer, are related, in part, to the disproportion of $n-6$ and $n-3$ FA concentrations in the human diet, especially when there is a high concentration of $n-6$ FA and a lack of $n-3$ FAs (Oliveira et al., 2011). In this study, more favorable $n-6: n-3$ FAs ratio was observed in rabbits receiving flaxseed supplementation.

\section{CONCLUSIONS}

This study provides the first dataset on carcass yield and quality, physicochemical characteristics, and FA profile of indigenous rabbits. The results show that indigenous rabbits contain a high proportion of PUFA (29.7\% of total fatty acids), and that supplementation of flaxseed favorably modulates the FAs composition of rabbit meat, with no negative effect on their growth performance and meat physicochemical quality. Moreover, lowest $(\mathrm{P}<0.05)$ concentration of medium chain and total saturated fatty acids, and higher concentration of PUFA was recorded with the diets containing higher levels of flaxseed or flaxseed oil. Compared to crushed flaxseed, the supplementation of oil was more effective in reducing saturated FAs and increasing PUFA level.

\section{ACKNOWLEDGEMENTS}

The Agriculture Linkages Program of Pakistan Agriculture Research Council Islamabad is acknowledged for financial support in this study.

\section{Statement of conflict of interest}

We certify that there is no conflict of interest with any funding organization.

\section{REFERENCES}

Arino, B., Hernandez, P., Pla, M. and Blasco, A., 2007. Comparison between rabbit lines for sensory meat quality. Meat Sci., 75: 494-498. https://doi. org/10.1016/j.meatsci.2006.08.013

AOAC, 1990. Official methods of analysis, $15^{\text {th }}$ Ed. Association of Official and Analytical Chemist, Washington, DC, USA.

Bianchi, M., Petracci, M. and Cavani, C., 2006. Effect of dietary inclusion of dehydrated Lucerne and whole linseed on rabbit meat quality. World Rabbit Sci., 14: 247-258,

Boccard, R., Buchter, L. and Casteels, E., 1981. Procedures for measuring meat quality 
characteristics in beef production experiments. Livest. Prod. Sci., 8: 358-397. https://doi. org/10.1016/0301-6226(81)90061-0

Bourre, J., 2004. Effect of increasing the omega-3 fatty acid in the diets of animals on the animal products consumed by humans. Med. Sci., 21: 773-779.

FAOSTAT, 2012. Livestock Pattern. The Statistics Division, FAO, Rome, http://faostat.fao.org/

Folch, J., Lees, M. and Sloane, S.G., 1957. A simple method for the isolation and purification of total lipids from animal tissues. J. biol. Chem., 226: 497 509.

Gelibolu, S., Yanar, Y., Ayce Genc, M. and Genc, E., 2018. Effect of Mannan oligosaccharide supplementation on body growth, fatty acid profile and organ morphology of gilthead seabream, Sparus aurata. Pakistan J. Zool., 50: 229-240. http://dx.doi. org/10.17582/journal .pjz/2018.50.1.229.240

Grau, R. and Fleischmann, O., 1957. Sodium chloride influencing meat swelling and improving the waterbinding capacity. Fleischwirtschaft, 9: 252.

Habib, G., Khan, N.A., Sultan, A. and Ali, M., 2016. Nutritive value of common tree leaves for livestock in the semi-arid and arid range lands of Northern Pakistan. Livest. Sci., 184: 64-70. https://doi. org/10.1016/j.livsci.2015.12.009

Hernandez, P., Cesari, V. and Blasco, A., 2008. Effect of genetic rabbit lines on lipid content, lipolytic activities and fatty acid composition of hind leg meat and perirenal fat. Meat Sci., 78: 485-491. https://doi.org/10.1016/j.meatsci.2007.07.018

$\mathrm{Hu}$, F.B. and Willett, W.C., 2002. Optimal diets for prevention of coronary heart disease. J. Am. med. Assoc., 288: 2569-2578. https://doi.org/10.1001/ jama.288.20.2569

Kanatt, S.R., Chander, R. and Sharma, A., 2006. Effect of radiation processing of lamb meat on its lipids. Fd. Chem., 97: 80-86. https://doi.org/10.1016/j. foodchem.2005.03.024

Khan, N.A., Cone, J.W., Pellikan W.F., Khan, M.A. and Struick, P.C., 2011. Changes in fatty acid content and composition in silage maize during grain filling. J. Sci. Fd. Agric., 91: 1041-1049. https:// doi.org/10.1002/jsfa.4279

Khan, N.A., Booker, H. and Yu, P., 2014. Molecular structures and metabolic characteristics of protein in brown and yellow flaxseed with altered nutrient traits. J. Agric. Fd. Chem., 62: 6556-6564. https:// doi.org/10.1021/jf501284a

Khan, S., Khan, K., Shah, S.U. and Ahmad, N., 2014. A preliminary assessment of rabbit farming and its scope in Khyber Pakhtunkhwa province of
Pakistan. Sarhad J. Agric., 30: 369-373.

Khan, N.A., Booker, H. and Yu, P., 2015a. Effect of heating method on alteration of protein molecular structure in flaxseed: Relationship with changes in protein subfraction profile and digestion in dairy cows. J. Agric. Fd. Chem., 63: 1057-1066. https:// doi.org/10.1021/jf503575y

Khan, N.A., Farooq, M.W., Ahmad, N., Cone, J.W. and Hendriks, W.H., 2015b. Effect of species and harvest maturity on the fatty acid content and composition of tropical forages. J. Anim. Pl. Sci., 25: 739-746.

Khan, K., Khan, S., Khan, R., Sulatan, A. Khan, N.A. and Ahmad, N., 2016. Growth performane and meat quality of rabbits under different feeding regimes. Trop. Anim. Hlth. Prod., 48: 1661-1666. https://doi. org/10.1007/s11250-016-1140-4

Khan, K., Khan, S., Khan, N.A. and Ahmad, N., 2017a. Production perfrmoance of indigenous rabbirs under traditional and inensive porduction system in Northern Pakistan. J. Anim. Pl. Sci., 27: 75-81.

Khan, K., Khan, S., Ullah, S., Khan, N.A, Khan, I. and Ahmad, N., 2017b. Nutritive value, fiber digestibility and methane production potential of tropical forages in rabbits: Effect of species and harvest maturity. J. Anim. Pl. Sci., 27: 1094-1100.

Kouba, M., Benatmane, F., Blochet, J.E. and Mourot, J., 2008. Effect of a linseed diet on lipid oxidation, fatty acid composition of muscle, perirenal fat, and raw and cooked rabbit meat. Meat Sci., 77: 829834. https://doi.org/10.1016/j.meatsci.2008.03.029

Martin, C.A., Almeida, V.V., Ruiz, M.R., Visentainer, J.E.L. and Matshushita, M., 2006. Poly unsatrated fatty acid omega-3 and omega-6: importance and occurrence in foods. Braz. J. Nutr., 19: 761-770.

Molkentin, J., 2000. Occurrence and biochemical characteristics of natural bioactive substances in bovine milk lipids. Br. J. Nutr., 84: 47-53. https:// doi.org/10.1017/S0007114500002245

NRC, 1977. Nutrient requirements of rabbits. The National Academy Press, Washington, DC.

Oliveira, D., Ladeira, M., Chizzotti, M. and Machado, M., 2011. Fatty acid profile and qualitative characteristics of meat from Zebu steers fed with different oilseeds. J. Anim. Sci., 89: 2546-2555. https://doi.org/10.2527/jas.2010-3553

Peiretti, P., Mussa, P., Prola, L. and Meineri, G., 2007. Use of different levels of false flax (Camelina sativa L.) seed in diets for fattening rabbits. Livest. Sci., 107: 192-198. https://doi.org/10.1016/j. livsci.2006.09.015

Raes, K., Smet, D. and Sand, D., 2004. Effect of 
dietary fatty acids on incorporation of long chain polyunsaturated fatty acids and conjugated linoleic acid in lamb, beef and pork meat. Anim. Feed Sci. Technol., 113: 199-221. https://doi.org/10.1016/j. anifeedsci.2003.09.001

Russo, G.L., 2009. Dietary $n-6$ and $n$ - 3 polyunsaturated fatty acids: From biochemistry to clinical implications in cardiovascular prevention. Biochem. Pharmacol., 77: 937-946. https://doi. org/10.1016/j.bcp.2008.10.020

Simopoulos, A.P., 2001. N-3 fatty acids and human health: defining strategies for public policy. Lipids, 36: 83-89. https://doi.org/10.1007/s11745-0010687-7

Trebusak, T., Leva, A., Frankic, T., Salobir, J. and Pirman, T., 2014. Effect of dietary linseed oil and Ganoderma lucidum or olive leaves supplementation on fatty acid composition and oxidative status of rabbits. World Rabbit Sci., 22: 71-81. https://doi.org/10.4995/wrs.2014.1183

Trebusak, T., Levart, A., Voljc, M., Tomazin, U. and Pirman, T., 2011. The effect of linseed oil supplementation on performance, fatty acid composition and oxidative status of rabbits. Acta Agric. Slovinka, 98: 119-125. https://doi. org/10.2478/v10014-011-0028-2

Van Soest, P.V., Robertson, J. and Lewis, B., 1991. Methods for dietary fiber, neutral detergent fiber, and nonstarch polysaccharides in relation to animal nutrition. J. Dairy Sci., 74: 3583-3597. https://doi. org/10.3168/jds.S0022-0302(91)78551-2

Wood, J.D., Richardson, R.I., Nute, G.R., Fisher, A.V., Campo, M.M., Kasapidou, E., Sheard, R.R. and Enser, M., 2004. Effects of fatty acids on meat quality. Meat Sci., 66: 21-32. https://doi. org/10.1016/S0309-1740(03)00022-6 